\title{
Miejsca pamięci w przestrzeni Paryża. Tanatoturystyka
}

\section{Memorials in the space of Paris. Thanatourism}

\section{Streszczenie}

Zwiedzając Paryż, można zauważyć, jak pamięciowa warstwa przestrzeni miejskiej tworzy wielogłos działalności zinstytucjonalizowanej i upamiętniania rozproszonego - od muzeum martyrologicznego przez mauzoleum po interaktywne pomniki i sztukę uliczną. Autorka na przykładzie Paryża pokazuje, w jaki sposób przestrzeń miejska przesiąknięta jest przez różnego rodzaju świadectwa upamiętnienia, które jednocześnie stanowią destynacje dla rosnącej w popularność tanatoturystyki.

Słowa kluczowe: architektura, pamięć, komemoracja, przestrzeń miejska, tanatoturystyka, sztuka uliczna, street art, Paryż

\section{Abstract}

When visiting Paris, one can notice how the memory layer of urban space creates a polyphony of institutionalised activity and dispersed commemoration - from the martyrdom museum, through the mausoleum, to interactive monuments and street art. The author, using the example of Paris, tracks how urban space is steeped in various forms of commemoration, which at the same time are destinations for thanatotourism, which is growing in popularity.

Keywords: architecture, memory, communication, urban space, thanatourism, street art, Paris 


\section{W POSZUKIWANIU TRWOGI}

Paryż. Rok 2019. Skojarzenia są nieomal jednoznaczne. Widok płonącej Katedry Notre Dame wstrząsnął Europą i światem. W ciągu kilku dni następujących po pożarze Paryż zarejestrował oblężenie turystów ${ }^{1}$. Wiele osób chciało na własne oczy zobaczyć miejsce katastrofy - z żalu, z ciekawości, by doświadczyć pewnego rodzaju katharsis. Obrazy, które napełniają trwogą, mają niezwykłą moc estetyczną - wzniosłość negatywną².

Będąc w stolicy Francji niedługo po pożarze, można było zobaczyć próby zasłonięcia miejsca wydarzenia tymczasowym ogrodzeniem. Przestrzeń stała się tajemnicą - trochę ciekawi, a trochę przeraża i smuci. Stolica Francji staje dziś przed wielkim wyzwaniem, by średniowieczny symbol miasta w przyszłości nie stał się martwym pomnikiem, ani też miejscem wzbudzającym trwogę, a był otwarciem na nowe znaczenia z jednoczesnym zachowaniem pamięci o przeszłości.

\subsection{TANATOTURYSTYKA}

Podróżując po Paryżu, można natrafić na rozmaite miejsca pamięci. Pierre Nora, autor tego terminu, nie stworzył definicji zamkniętej, można więc rozumieć go jako zbiorowe wspomnienia z przeszłości, posiadające zinstytucjonalizowane formy³.

Tanatoturystyka to rodzaj turystyki, który polega na odwiedzaniu miejsc pamięci i przestrzeni trwogi - związanych ze śmiercią lub katastrofą ${ }^{4}$. Jej nazwa pochodzi od greckiego boga śmierci - Tanatosa. Liczba tanatoturystów rośnie przez ostatnie lata, a infrastruktura muzealno-turystyczna związana z wojnami i martyrologią w Europie Środkowej dynamicznie się rozwija ${ }^{5}$. Wiele z tych miejsc to przestrzenie związane z II wojną światową jako wydarzeniem, które zmieniło tożsamość świata i europejskich miast. Martin Winstone w książce Miejsca Holocaustu w Europie opisuje tysiące obszarów przywołujących okropności Zagłady, tworząc nieomal przewodnik tanatoturystyczny ${ }^{6}$. Zauważalny memory boom ${ }^{7}$ w związku z przywracaniem tematyki II wojny światowej wpływa na rozwój tanatoturystyki, jednak jej zakres jest o wiele szerszy i obejmuje także miejsca kataklizmów i ataków terrorystycznych.

\section{WSPOMNIENIE ZAGŁADY}

\subsection{POMNIK MĘCZENNIKÓW DEPORTACJI}

Pomnik Męczenników Deportacji to założenie architektoniczne z 1962 roku na wschodnim cyplu île de la Cité, zaprojektowane przez Georges'a-Henriego Pingussona. Upamiętnia 200000 deportowanych z Francji Vichy do obozów koncentracyjnych podczas II wojny światowej. Pomnik zlokalizowano na tyłach katedry Notre Dame w reprezentatywnym terenie 
zielonym - Île-de-France. Założenie jest dyskretnie rozbudowane poniżej poziomu terenu jego widoczna z daleka część sprawia wrażenie niskiego kamiennego muru, który dodatkowo eksponuje widok otoczenia mostu Pont de la Tournelle. Do właściwego pomnika prowadzą wąskie schody. Kiedy obserwator po nich schodzi, otacza go coraz wyższy mur - przechodzi przez przestrzeń klaustrofobiczną, obezwładniającą i traci kontakt wzrokowy z otoczeniem. Zapadnięty plac otoczony jest wysokimi murami, przestrzeń wydaje się odosobniona, niemal odrealniona i abstrakcyjna. Całość założenia wykonano z jednolitego materiału: betonu pokrytego białym cementem - agregatem kamieni wydobytych z symbolicznych obszarów we Francji ${ }^{8}$. Na wschodniej ścianie znajduje się jedyny otwór w murze ograniczony broną, przez który można zobaczyć Sekwanę. Przysłania go jednak dramatyczna, ażurowa forma rzeźbiarska stanowiąca symboliczną kurtynę, przeszkodę stojącą na drodze ku otwartej przestrzeni. $\mathrm{Na}$ osi otworu ulokowano wejście do krypty. Strzegą go dwie, monolityczne bryły kamienia, uniesione nad posadzką, dodając mu dynamiki i niepokoju. Dziedziniec stanowi przestrzeń przejściową między zielonym, żywotnym placem île-de-France, a kryptą - miejscem ciszy, odosobnienia i wspomnienia śmierci.

Rzut podziemnego wnętrza to symetryczna sekwencja pomieszczeń, wynikająca z kształtu cypla. W centralnej jego części zlokalizowano sześcioboczne pomieszczenie, na osi którego znajduje się reprezentatywny korytarz - miejsce pochówku nieznanego deportowanego ${ }^{9}$. Długa ciemna galeria jest obłożona szklanymi elementami symbolizującymi zabitych więźniów nazistowskich obozów. W dwóch pobocznych korytarzach umieszczono pomieszczenia o charakterze ekspozycyjnym. Znajdują się tu także puste pomieszczenia, do których z założenia nie ma wstępu. Podobnym działaniem, wykorzystującym brak i pustkę, charakteryzują się tzw. kontrpomniki, które szeroko opisuje James E. Young ${ }^{10}$.

Przestrzeń pomnika wypełniona została symbolicznymi, komemoratywnymi ${ }^{11}$ elementami oraz poezją wyrzeźbioną na murach. Na ścianach bocznych galerii można znaleźć płaskorzeźby z wyrytymi nazwami obozów nazistowskich - za nimi złożona jest obozowa gleba oraz popioły z krematoriów ${ }^{12}$. Ten niezwykły projekt prowadzi w przestrzeni świadomą narrację to za nią podąża obserwator i stopniowo coraz głębiej angażuje się w treści zawarte w pomniku. Pomnik ten może być uznany za jeden z dowodów na to, że architektura (i jej narracja) jest jednym z najsilniejszych przekaźników pamięci i ogniw podtrzymujących tożsamość. Autorka, podążając za Anną M. Wierzbicką, rozumie narrację znaczeniową architektury jako oś opowieści o danym miejscu i historii, łączącą elementy o charakterze znaczeniowym ${ }^{13}$.

\subsection{MUZEUM PAMIĘCI SHOAH}

Istotnym paryskim miejscem honorującym pamięć II wojny światowej jest Mémorial de la Shoah - Muzeum Pamięci Shoah ${ }^{14}$. Jest to przestrzeń wykorzystująca architekturę zarówno jako funkcjonalny środek przekazywania informacji, a także jako artystyczne medium 
narracyjne. Muzeum zaprojektowane zostało przez Alexandrego Perzitza (ocalałego z Holokaustu) w latach 50. XX wieku. Funkcjonuje jako centrum dokumentacji i gromadzi zbiory związane z historią Żydów podczas II wojny światowej ${ }^{15}$. Budynek znajduje się na działce narożnej, jednak celowo został odsunięty od zwartej tkanki miejskiej i od frontu sprawia wrażenie wyrazistego budynku wolnostojącego.

Wzdłuż Allée des Justes de France, na murze otaczającym muzeum, znajduje się tzw. Ściana Sprawiedliwych, na której można przeczytać nazwiska Sprawiedliwych Wśród Narodów Świata. Zatem już z ulicy można doświadczyć jednej z symbolicznych przestrzeni pamięci. Ascetyczną elewację frontową buduje gładki prostokąt wzbogacony jedynie o płaskorzeźbę gwiazdy Dawida oraz o inskrypcje w języku francuskim oraz jidysz. Kontrastuje z nią elewacja boczna - ozdobna, dwuwarstwowa. Jej zewnętrzną część tworzy ażurowa sekwencja geometrycznych wzorów układających się w powieloną gwiazdę Dawida. Ten sam zabieg Perzitz zastosował we frontowej elewacji paryskiej Synagogue de la Roquette ${ }^{16}$.

Na zewnątrz budynku znajduje się kolejna, otoczona murami, symboliczna przestrzeń. To niewielki dziedziniec przecięty przez dwie ściany - tzw. Mur Nazwisk. Wypisanych jest na nich ponad 76 tysięcy nazwisk francuskich Żydów, ofiar Zagłady, co nadaje ścianom rozdrobnioną fakturę. Po raz kolejny wyrazem bólu i sposobem na uczczenie ofiar staje się proste, architektoniczno-rzeźbiarskie rozwiązanie. Ciężar i znaczenie treści wręcz oczekuje prostej formy, która prędzej emanować będzie brakiem niż przepychem, jak we wspomnianych już kontrpomnikach.

Główną strefę wejściową poprzedza niewielki dziedziniec. To tu odwiedzający poruszają się wokół cylindrycznej, spatynowanej formy, na której uwieczniono nazwy największych nazistowskich obozów koncentracyjnych i obozów śmierci. Forma jednocześnie maskuje otwór doświetlający kryptę znajdującą się pod dziedzińcem. Staje się łącznikiem między strefą otwartą i podziemną.

Krypta znajduje się na osi głównych schodów - zwiedzający natrafiają na nią na początku zwiedzania. Naprzeciwko schodów znajduje się ściana z biblijnym cytatem w języku jidysz. To oszczędnie oświetlone pomieszczenie skupia się wokół niskiej, granitowej bryły w kształcie sześciobocznej gwiazdy z płonącym lampionem pośrodku. Znajduje się tu ziemia sprowadzona z miejsc Zagłady. Dalsza część muzeum zbudowana jest na zasadzie linearnej kontynuacji przestrzeni, która przenika przez porządkujące ją przegrody. Ekspozycja nosi znamiona narracyjnej - duży nacisk położony jest na związki przyczynowo-skutkowe w historii - obecnie głównego nurtu muzealniczego. 


\section{PAMIĘĆ NAJNOWSZA}

Nie każde upamiętnienie w przestrzeni publicznej ma charakter architektoniczny lub rzeźbiarski, a jednak konstytuuje się jako miejsce pamięci. Następujące przykłady ukazują, jak pamięciowa warstwa przestrzeni miejskiej może mówić wielogłosem zarówno działalności zinstytucjonalizowanej, jak i upamiętniania rozproszonego, „oddolnego” - charakterystycznego dla dzisiejszej, zindywidualizowanej kultury multimedialnej ${ }^{17}$.

\subsection{BATACLAN}

Nie sposób mówić o pamięci w przestrzeni Paryża, pomijając wydarzenia najnowsze. Bataclan to nazwa sali koncertowej ${ }^{18}$, w której 13 XI 2015, podczas koncertu amerykańskiego zespołu Eagles of Death Metal, doszło do strzelaniny. Zginęło ok. 130 osób ${ }^{19}$. Bezpośrednio po tragedii przed wejściem do teatru Paryżanie spontanicznie kładli kwiaty, listy czy świeczki, tworząc miejsce pamięci. Zatem „charakter przestrzeni nie jest wyłącznie wynikiem działań plastyczno-kompozycyjnych, jest przejawem tożsamości wspólnoty i kształtowanej przez nią kultury"20. Światowej sławy artysta sztuki ulicznej - Banksy - zostawił po sobie dzieło interpretowane jako upamiętnienie zamachu. To białe graffiti na tle czarnych drzwi pożarowych Bataclanu, przedstawiające zawoalowaną kobietę w żałobnej pozie. Dzieło zostało skradzione ${ }^{21}$. Bataclan prawie po roku od masakry wrócił do ponownego funkcjonowania, a przestrzeń przed wejściem odzyskała dawną funkcję i charakter. Dzisiaj upamiętnienie zdarzenia stanowi jedynie tablica na elewacji budynku przy głównym wejściu do teatru.

\subsection{CHARLIE HEBDO}

Siedziba redakcji Charlie Hebdo - francuskiego tygodnika satyrycznego - to inne paryskie miejsce, w którym doszło do tragedii w 2015 roku. 7 stycznia w wyniku zamachu zginęło 12 osób. Niedługo później odbyły się uroczystości upamiętniające ofiary, budynek redakcji otaczały kwiaty i światła oraz ruszyła internetowa akcja solidarności z ofiarami. „Je suis Charlie"22 - slogan ukuty z tej okazji - momentalnie rozprzestrzenił się w mediach społecznościowych zarówno jako manifest przeciwko terroryzmowi, jak i deklaracja zaufania wobec wolności prasy. Hasztag ${ }^{23}$ \#jesuischarlie zaraz po zamachu był tweetowany w tempie 6500 razy na minutę, stając się jednym z najpopularniejszych w historii Twittera ${ }^{24}$. Przestrzeń internetowa stała się pozamaterialnym, globalnym miejscem pamięci.

Dziś przy wejściu do budynku redakcji można zobaczyć fizyczne formy upamiętnienia wydarzenia. Na ścianie wisi nieomal niedostrzegalna tablica upamiętniająca, powieszona na 
zbyt dużej wysokości, aby swobodnie przeczytać jej treść. Obok jednak znajduje się mural artysty ulicznego $\mathrm{C} 215^{25}$, który, tym razem rezygnując z typowych dla siebie krzykliwych kolorów, dokonał upamiętnienia mniej oficjalnego, przystępnego, tworzącego tożsamość. Mural przedstawiający portrety osób, które zginęły w zamachu koresponduje z pozostałymi dziełami sztuki ulicznej ${ }^{26}$. Ich sekwencja tworzy skontrastowaną przestrzeń - z jednej strony jest ruchliwą i przepełnioną funkcjonalizmem jezdnią, a z drugiej miejscem zadumy i pamięci.

\section{NA OBRZEŻACH PARYŻA}

Bardziej dociekliwym tanatoturystom Paryż oferuje również inne miejsca warte odwiedzin. Sam słynny cmentarz Père-Lachaise jest miejscem kultowym. Warto jednak wspomnieć też lokalizacje oddalone od centrum.

Mont Valérien to fort z 1841 roku, położony na wzniesieniu w obrębie île-de-France, na terenie gminy Suresnes. Jest miejscem licznych wiekopomnych paryskich wydarzeń od oblężenia miasta w XIX wieku po masowe egzekucje w czasie II wojny światowej. Dziś jest reprezentatywnym miejscem pamięci, goszczącym państwowe uroczystości.

La Cité de la Muette to przykład wielkoskalowego, budżetowego apartamentowca w kształcie litery „U” w gminie Drancy, według projektu Eugène Beaudouina i Marcela Lodsa ${ }^{27}$. To niezwykłe modernistyczne założenie, będące odpowiedzią na przeludniony Paryż, w czasie II wojny światowej zostało przeznaczone na obóz jeniecki, a potem na obóz przejściowy dla Żydów. Dziś na osi „U” można zobaczyć założenie pomnikowe upamiętniające Zagładę, znane jako Mémorial de la Shoah de Drancy.

\section{PAMIĘĆ OFICJALNA I SPONTANICZNA}

Na przykładzie Paryża można obserwować, jak zmieniają się kryteria definiowania i oceny miejsca pamięci. Pamięć oficjalna ${ }^{28}$ nieraz realizuje się w spektakularnych obiektach, jak upamiętnienia poległych w I wojnie światowej - monumentalna ściana z płaskorzeźbą przy Place du Trocadéro - À la gloire de l'Armée française 1914-1918 (1956) ${ }^{29}$, oraz pomnik linearny przy Père-Lachaise - Monument aux Morts Parisiens 14-18 Mur du Père Lachaise $(2018)^{30}$.

Szczególną formą oficjalnego upamiętnienia jest pomnik wojny w Algierii, walk w Maroku i Tunezji, który interaktywnością stara się zaangażować odbiorcę. To dzieło Gérarda Collina-Thiébauta, zainaugurowane w 2002 roku. Stanowią go trzy kilkumetrowe, betonowe filary, rozcięte na froncie. Ukryte w szczelinach ekrany wyświetlają nazwiska poległych w konfliktach z II połowy XX wieku żołnierzy. Każdy wyświetla litery w innym kolorze tak, aby razem tworzyły francuską flagę ${ }^{31}$. W trzeciej, czerwonej części wyświetlane są nazwiska, które można przywołać 
dzięki dotykowemu ekranowi. To niezwykle prosta, symetryczna kompozycja, oszczędna w środkach wyrazu, jednak współczesna i otwarta na interakcję z obserwatorem.

Pamięci zinstytucjonalizowanej przeciwstawia się ta „oddolna”, spontaniczna. Jej przejawy można dostrzec na cmentarzu Père-Lachaise przy grobach ikon kultury takich jak Oscar Wilde czy Jim Morrison. Odwiedzający mieli zwyczaj całować pomnik nagrobny Wilde’a, zostawiając ślad czerwonej szminki jako symbol żywej o nim pamięci. Z powodu tego romantycznego, acz destrukcyjnego zwyczaju, kamień ogrodzono szkłem ze względów konserwatorskich. Szkła także nie wolno całować. Z kolei przy grobie Morrisona rośnie drzewo, na którym odwiedzający zwykli - w rebelianckim duchu artysty - przyklejać gumę do żucia na znak swojej obecności.

\section{PODSUMOWANIE}

Kojarzący się z Erosem Paryż równie mocno tkwi w objęciach Tanatosa. Stolica Francji to od zawsze było źródło nieskończonych inspiracji, ale i zagrożeń - upamiętnionych na wiele sposobów, przez co staje się miejscem atrakcyjnym dla tanatoturystów. Można tu zwiedzić i poznać wiele przestrzeni komemoratywnych - od muzeum martyrologicznego, mauzoleum, po interaktywne pomniki, sztukę uliczną, jak i globalne, internetowe miejsca pamięci zapoczątkowane tragedią. Jak każde miasto Paryż jest zapisem długotrwałej historii, ludzi i wydarzeń w przestrzeni, a upamiętnianie jest formą praktyki kulturowej, która zawsze jest w ruchu i nigdy nie zostanie ukończona. 


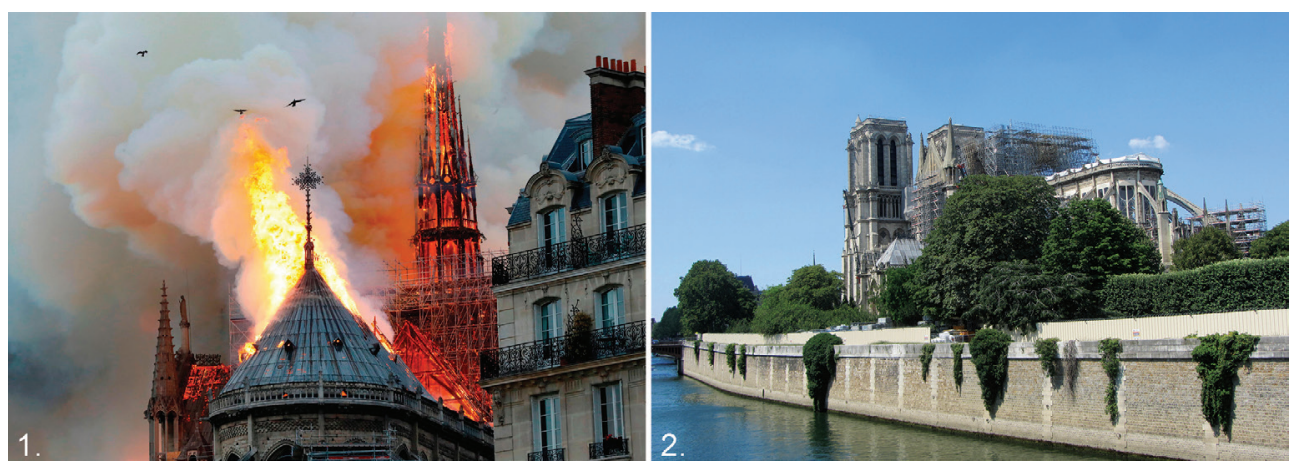

II. 1. Płonąca katedra Notre Dame, Paryż, Francja (źródło: https://cdn.cnn.com/cnnnext/dam/ assets/190415144952-notre-dame-cathedral-fire-paris-witness-james-janega-bpr-nr-vpx-00021312.jpg) II. 2. Katedra Notre Dame po pożarze, Paryż, Francja, lipiec 2019 (fot. autorka)
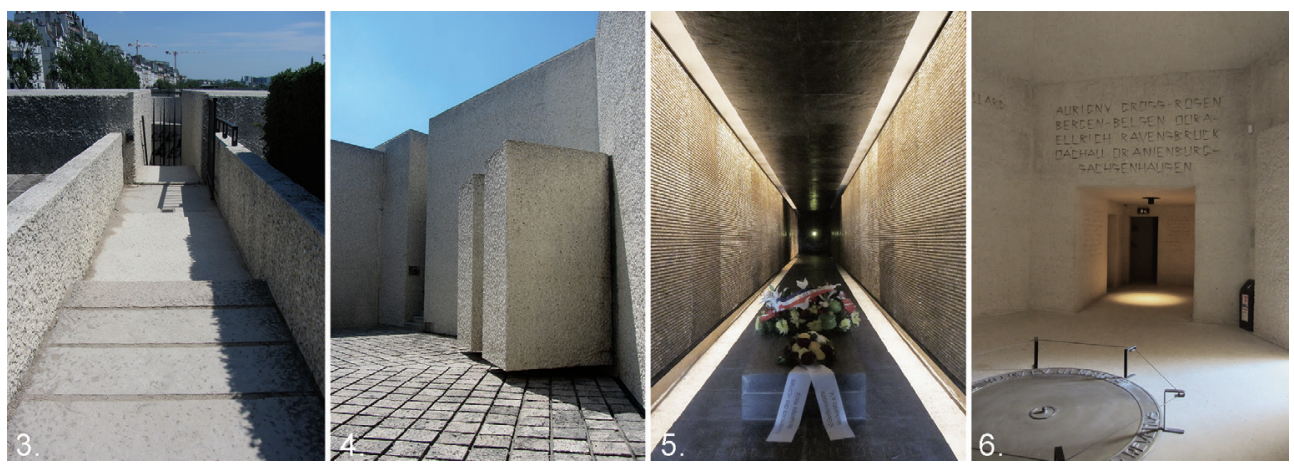

II. 3-6. Pomnik Męczenników Deportacji, Paryż, Francja, lipiec 2019 (fot. autorka)
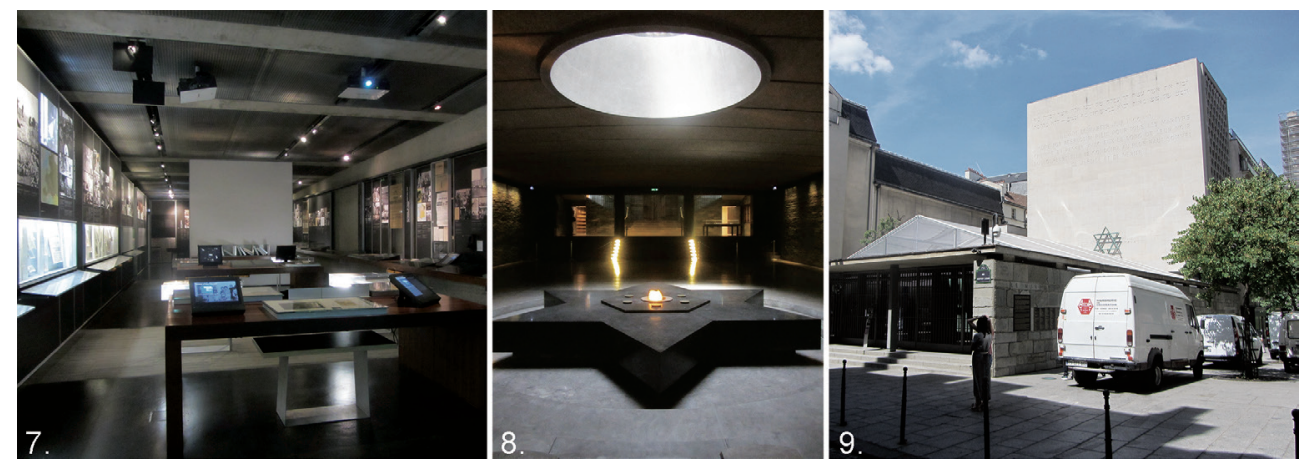

II. 7-9. Muzeum Pamięci Shoah, Paryż, Francja, lipiec 2019 (fot. autorka) 

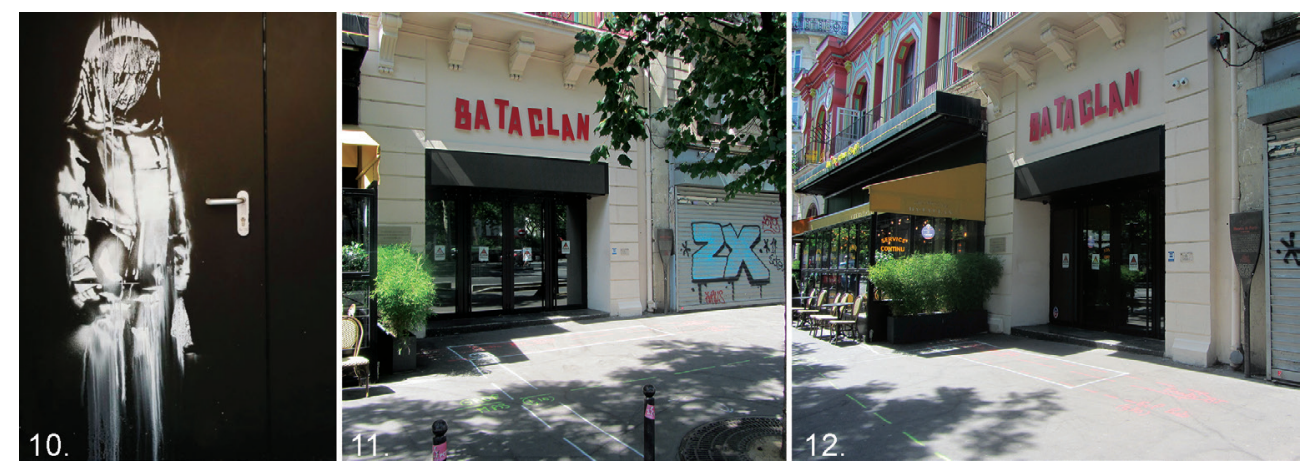

II. 10. Bez tytułu, (prawdopodobnie) Banksy, Paryż, Francja (źródło:https://abcnews.go.com/ International/banksy-tribute-paris-terror-attack-victims-stolen-bataclan/story?id=60648284) II. 11-12. Bataclan, Paryż, Francja, lipiec 2019 (fot. autorka)

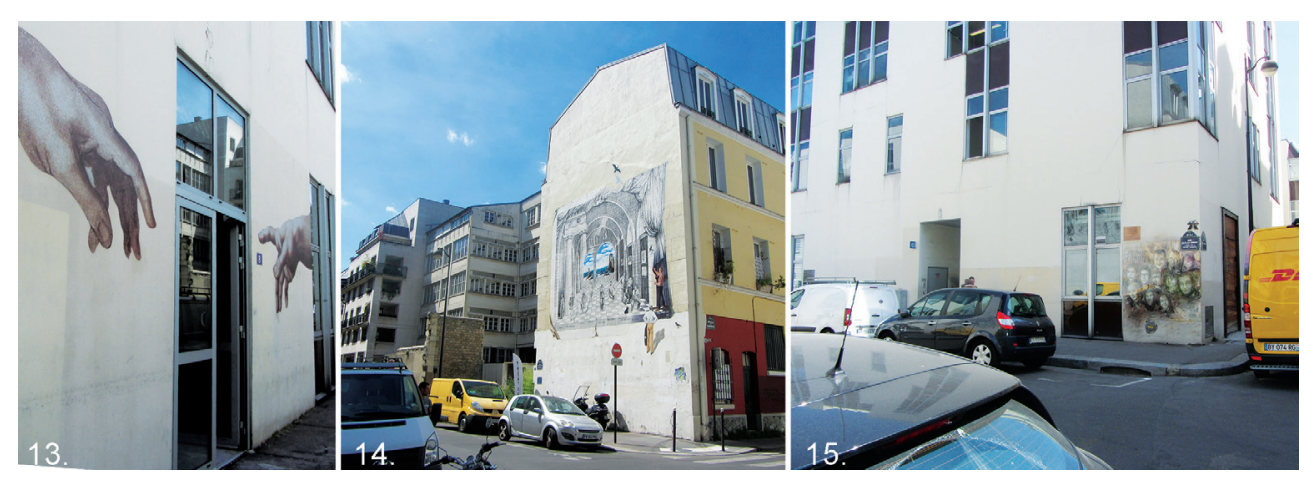

II. 13, 15. Wejście do budynku redakcji Charlie Hebdo, Paryż, Francja, lipiec 2019 (fot. autorka) II. 14. Przestrzeń przed wejściem do budynku redakcji Charlie Hebdo, Paryż, Francja, lipiec 2019 (fot. autorka) 


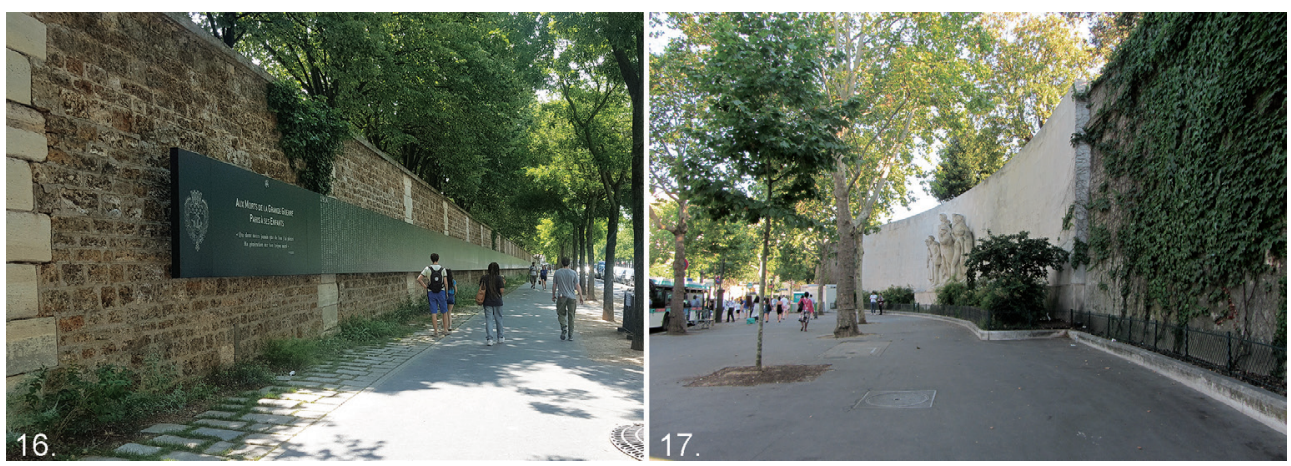

II. 16. Monument aux Morts Parisiens, Paryż, Francja, lipiec 2019 (fot. autorka)

II. 17. À la gloire de l'Armée française 1914-1918, Paryż, Francja, lipiec 2019 (fot. autorka)
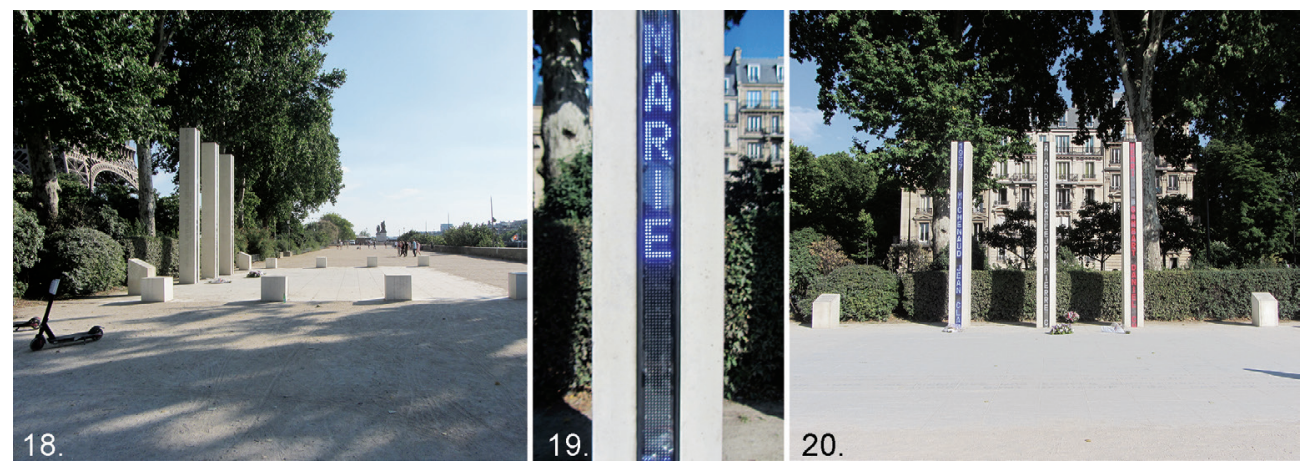

II. 18-20. Pomnik wojny w Algierii, walk w Maroku i Tunezji, Paryż, Francja, lipiec 2019 (fot. autorka)
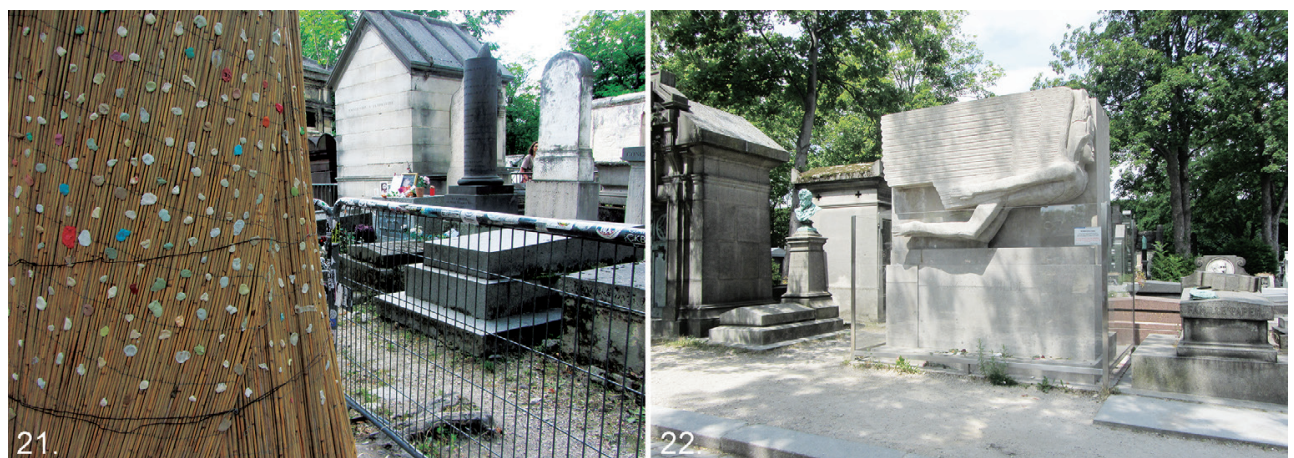

II. 21. Grób Jima Morrisona, Cmentarz Père-Lachaise, Paryż, Francja, lipiec 2019 (fot. autorka)

II. 22. Grób Oscara Wilde’a, Cmentarz Père-Lachaise, Paryż, Francja, lipiec 2019 (fot. autorka) 


\section{PRZYPISY}

1 https://fakty.interia.pl/raporty/raport-pozar-notre-dame/relacje/news-interia-w-paryzumiasto-przezywa-oblezenie-turystow,nld,2941221

2 Fascynacja zjawiskami moralnie negatywnymi. Więcej: A. Berleant, Wrażliwość i zmysły. Estetyczna przemiana świata człowieka, Polskie Towarzystwo Estetyczne, Kraków 2010.

3 A. Szpociński, Miejsca pamięci (lieux de mémoire), "Teksty drugie” 4/2008, s. 11-20.

4 S. Tanaś, Tanatoturystyka - turystyczne wykorzystanie przestrzeni śmierci, [w:] Miejsce po miejsce bez, Muzeum Historyczne Miasta Krakowa, Kraków 2015.

5 M. Muszel, Tanatoturystyka-mroczna strona turystyki, „,Kultura i Społeczeństwo” 1/2007, s. 151.

6 M. Winstone, Miejsca Holocaustu w Europie, Bellona, Warszawa 2017.

7 W tłumaczeniu: gorączka upamiętniania. Więcej: M. Saryusz-Wolska, Spotkania czasu z miejscem. Studia o pamięci i miastach, Wydawnictwa Uniwersytety Warszawskiego, Warszawa 2011, s. 9; G. Marzec, Ekonomia pamięci, Instytut Badań Literackich PAN, Warszawa 2016, s. 12.

8 http://web.archive.org/web/20070820001159/www.defense.gouv.fr/sga/enjeux_defense/ histoire_et_patrimoine/memoire/monuments/memoriaux/memorial_des_martyrs_de_ la_deportation

9 Ofiara obozu w Neustadt.

10 J.E. Young, The Counter-Monument: Memory against Itself in Germany Today, "Critical Inquiry" 2(18)/1992, s. 267-296.

${ }^{11}$ Komemoracja lub upamiętnienie - kulturowa forma uobecniania minionych wydarzeń bądź osób w celu oddania im czci przez określoną grupę społeczną, która w ten sposób potwierdza własną tożsamość - M. Napiórkowski, upamiętnienie, [w:] M. Saryusz-Wolska, R. Traba, Modi memorandi. Leksykon kultury pamięci, Wydawnictwo Naukowe Scholar, Warszawa 2014, s. 509.

12 http://arts-plastiques.ac-rouen.fr/grp/sculpture_commemorative/martyrs_deportation_ paris.html

13 A.M. Wierzbicka, Architektura jako narracja znaczeniowa, Oficyna Wydawnicza Politechniki Warszawskiej, Warszawa 2013, s. 20.

${ }^{14}$ M. Winstone, Miejsca Holocaustu w Europie, Bellona, Warszawa 2017, s. 37.

1518 stycznia 2019 r. Mémorial de la Shoah podpisało umowę współpracy z polskim Muzeum Historii Żydów Polskich POLIN mające na celu relacje naukowe, dydaktyczne, szkoleniowe oraz wymianę doświadczeń i dobrych praktyk między instytucjami. Więcej: https://www. polin.pl/pl/aktualnosci/2019/01/22/umowa-o-wspolpracy-muzeum-polin-i-memorial-dela-shoah-w-paryzu.

16 Współautorem był Arthur-Georges Héaume.

17 W.J. Burszta, Upamiętnianie jako forma praktyki kulturowej, [w:] Znaki (nie)pamięci. Teoria i praktyka upamiętniania w Polsce, red. M. Fabiszak, A.W. Brzezińska, M. Owsiński, Universitas, Kraków 2016, s. 15. 
18

19

Bataclan jest jednym z czterech miejsc, gdzie tego dnia wydarzył się atak terrorystyczny. Pozostałe to: Le Petit Cambodge („Mała Kambodża”) w 10. dzielnicy, w centrum handlowo-rozrywkowym Les Halles w 1. dzielnicy oraz w okolicy stadionu Stade de France $w$ dzielnicy Saint-Denis.

${ }^{20}$ A. Tejszerska, Tożsamość i tradycja-niezbywalne wartości przestrzeni miejskiej, [w:] Wartość a przestrzeń architektoniczna, red. A. Kurkowska, I. Mikołajczyk, Wydawnictwo Uczelniane Politechniki Koszalińskiej, Koszalin 2017, s. 91.

21 https://www.theguardian.com/world/2019/jan/26/thieves-drive-off-with-banksy-mural-on-bataclan-fire-door oraz https://abcnews.go.com/International/banksy-tribute-paris-terror-attack-victims-stolen-bataclan/story?id=60648284

22 Tłumaczenie: Jestem Charlie.

${ }^{23}$ Hasztag (hashtag) - słowo lub fraza poprzedzona znakiem \# (hash), ułatwiające znalezienie i grupowanie elementów (zdjęć, tweetów itp.); hasztag, https://sjp.pl/hasztag.

24 https://www.telegraph.co.uk/news/worldnews/europe/france/11336879/Paris-CharlieHebdo-attack-Je-Suis-Charlie-hashtag-one-of-most-popular-in-Twitter-history.html

${ }^{25}$ C215 - Christian Guémy, paryski artysta uliczny; http://www.streetartbio.com/c215.

26 Przy wejściu do redakcji znajduje się również grafika ukazująca dłonie zapożyczone ze Stworzenia Adama Michała Anioła. Po przeciwnej stronie ulicy znajduje się mural pokrywający ścianę budynku - symboliczna rycina przywołująca pamięć o mistrzach piórka, jak Szekspir czy Wiktor Hugo.

27 M. Winstone, Miejsca Holocaustu w Europie, Bellona, Warszawa 2017, s. 42-45.

28 Pamięć oficjalna - taka, która tworzy tożsamość narodu i mity historyczne.

29 http://memorial14-18.paris.fr/memorial/jsp/site/Portal.jsp?page=directory\&id_directory_record=23\&view_directory_record=1

30 https://www.appl-lachaise.net/appl/article.php3?id_article=6411

${ }^{31}$ W pierwszym filarze można przeczytać nazwiska francuskich poległych w Afryce Północnej, drugi zaś wspomina okres wojny algierskiej i pamięć o wszystkich, którzy zniknęli po zawieszeniu broni. 


\section{BIBLIOGRAFIA}

Berleant A., Wrażliwość i zmysły. Estetyczna przemiana świata człowieka, Polskie Towarzystwo Estetyczne, Kraków 2010.

Burszta W.J., Upamiętnianie jako forma praktyki kulturowej, [w:] Znaki (nie)pamięci. Teoria i praktyka upamiętniania w Polsce, red. M. Fabiszak, A.W. Brzezińska, M. Owsiński, Universitas, Kraków 2016.

Erll A., Kultura pamięci, Wydawnictwo Uniwersytetu Warszawskiego, Warszawa 2018.

Gyurkovich M., Współczesne muzeum w strukturze miasta, Wydawnictwo Politechniki Krakowskiej im. Tadeusza Kościuszki, Kraków 2007.

Marzec G., Ekonomia pamięci, Instytut Badań Literackich PAN, Warszawa 2016.

Muszel M., Tanatoturystyka - mroczna strona turystyki, „Kultura i Społeczeństwo” 1/2007, 151-168.

Saryusz-Wolska M., Spotkania czasu z miejscem. Studia o pamięci i miastach, Wydawnictwa Uniwersytetu Warszawskiego, Warszawa 2011.

Saryusz-Wolska M., Traba R., Modi memorandi. Leksykon kultury pamięci, Wydawnictwo Naukowe Scholar, Warszawa 2014.

Szpociński A., Miejsca pamięci (lieux de mémoire), „Teksty drugie” 4/2008, 11-20.

Tanaś S., Tanatoturystyka - turystyczne wykorzystanie przestrzeni śmierci, [w:] Miejsce po miejsce bez, praca zbiorowa, Muzeum Historyczne Miasta Krakowa, Kraków 2015.

Tejszerska A., Tożsamość i tradycja-niezbywalne wartości przestrzeni miejskiej, [w:] Wartość a przestrzeń architektoniczna, red. A. Kurkowska, I. Mikołajczyk, Wydawnictwo Uczelniane Politechniki Koszalińskiej, Koszalin 2017.

Wierzbicka A.M., Architektura jako narracja znaczeniowa, Oficyna Wydawnicza Politechniki Warszawskiej, Warszawa 2013.

Winstone M., Miejsca Holocaustu w Europie, Bellona, Warszawa 2017.

Young J.E., The Counter-Monument: Memory against Itself in Germany Today, "Critical Inquiry" 2(18)/1992, 267-296.

http://arts-plastiques.ac-rouen.fr/grp/sculpture_commemorative/martyrs_deportation_paris. html (dostęp: 20.09.2019).

http://memorial14-18.paris.fr/memorial/jsp/site/Portal.jsp?page=directory\&id_directory_ record=23\&view_directory_record=1 (dostęp: 25.09.2019).

http://web.archive.org/web/20070820001159/www.defense.gouv.fr/sga/enjeux_defense/ histoire_et_patrimoine/memoire/monuments/memoriaux/memorial_des_martyrs_de_ la_deportation (dostęp: 20.09.2019).

http://www.streetartbio.com/c215 (dostęp: 03.10.2019).

https://abcnews.go.com/International/banksy-tribute-paris-terror-attack-victims-stolenbataclan/story?id=60648284 (dostęp: 12.09.2019). 
https://fakty.interia.pl/raporty/raport-pozar-notre-dame/relacje/news-interia-w-paryzumiasto-przezywa-oblezenie-turystow,nld,2941221 (dostęp: 27.09.2019).

https://sjp.pl/hasztag (dostęp: 3.10.2019).

https://www.appl-lachaise.net/appl/article.php3?id_article=6411 (dostęp: 25.09.2019). https://www.polin.pl/pl/aktualnosci/2019/01/22/umowa-o-wspolpracy-muzeum-polin-imemorial-de-la-shoah-w-paryzu (dostęp: 12.09.2019).

https://www.telegraph.co.uk/news/worldnews/europe/france/11336879/Paris-CharlieHebdo-attack-Je-Suis-Charlie-hashtag-one-of-most-popular-in-Twitter-history.html (dostęp: 12.09.2019).

https://www.theguardian.com/world/2019/jan/26/thieves-drive-off-with-banksy-mural-onbataclan-fire-door (dostęp: 12.09.2019). 